\title{
Obstructive Sleep Apnea and Metabolic Syndrome: New Directions in this Association
}

\author{
Oliveira e Silva $\mathrm{L}^{1 *}$, Rizzatti Galhardo $\mathrm{F}^{1}$, Maior $\mathrm{ML}^{2}$, Tufik $\mathrm{S}^{1}$, Bittencourt $\mathrm{L}^{1}$ and Togeiro $\mathrm{SM}^{1}$ \\ ${ }^{1}$ Departamento de Psicobiologia-Universidade Federal de São Paulo, Brazil \\ ${ }^{2}$ Universidade Federal do Rio de Janeiro, Brazil
}

Submission: December 18, 2017; Published: January 05, 2018

*Corresponding author: Luciana Oliveira e Silva, Departamento de Psicobiologia, Universidade Federal de São Paulo, Brazil, Tel: +55 1-121-490150; Email: luciana.fisioterapia@gmail.com

\section{Introduction}

Obstructive Sleep Apnea (OSA) has become the most prevalent respiratory sleep disorder and imposes greater already mentioned public health burden [1,2]. Risk factors for metabolic syndrome (MetS) are frequently observed in individuals with OSA $[3,4]$. The association between OSA and MetS has been recognized as "Syndrome Z" [3]. It's well known that moderate and severe OSA are related to cardiovascular and metabolic consequences mortality [5-9]. However, there is some evidence that OSA contributes to the development or exacerbated MetS / insulin resistance/type 2 diabetes mellitus [10].

The pathophysiology of OSA is complex and multifactorial and obesity is the main factor for this sleep respiratory disorder. Metabolic disorders/obesity share with OSA common intermediate pathogenic pathways involved in the interplay between these conditions [11]. Intermittent hypoxemia and hypercapnia, arousals from sleep, swings in intrathoracic pressure during obstructive respiratory events (apneas and hypopneas) trigger pathogenic pathways such as increased in the autonomic nervous system and inflammatory activity, alterations in adipokine levels and endothelial function that are associated with cardiovascular and metabolic consequences $[12,13]$

Additionally, dysregulation of the hypothalamic-pituitaryadrenal (HPA) axis was also described in patients with severe OSA that could be a further factor for MetS $[14,15]$. As above mentioned it is well known that the main confounder for exacerbating cardiometabolic risk in OSA is obesity [16] and previous studies have adequately analyzed the influence of visceral obesity for this risk in these patients $[11,17]$.

More recently, the genetic basis of the inflammatory response in OSA have been explored and contributing to explain the relation between OSAS, obesity and insulin resistance
[18]. Insulin Resistance increases insulin-stimulated hepatic lipogenesis and causes a general accumulation of ectopic lipids [19]. The intracellular accumulation of lipids then triggers defects in insulin signaling and induces IR in muscle and liver [20-23] initiating a vicious cycle. According to recent studies, high values of TG/HDL-c ratio has been identified as a possible early atherogenic marker in different populations, especially in moderate-severe OSA $[24,25]$. Therefore, this ratio could be related to Insulin Resistance in patients with remarkable OSA $[25,26]$.

In addition, polymorphisms of Apolipoproteins (APOE $\varepsilon 2$, and APOE $\varepsilon 4$ ) have been investigated in OSA patients $[27,28]$. However, despite researchers have demonstrated the several Apo lipoprotein polymorphisms are associated with diabetes susceptibility and/or lipid metabolism, further studies with high sample size are necessary for this field [28]. The aim of this review is to highlight the relationship between OSA and metabolic disturbance addressing the pathophysiologic mechanisms, confounding factors, significant gaps in research and future directions [29]. In addition, The International Diabetes Federation published clinical practice recommendations suggesting that OSA patients should be routinely screened for markers of metabolic disturbance and cardiovascular risks such as waist circumference, blood pressure, and fasting lipid and glucose levels. It also recommends that the possibility of OSA should be considered in the assessment of all patients with type 2 diabetes mellitus and metabolic syndrome [10].

\section{References}

1. Tufik S, Santos Silva R, Taddei JA, Bittencourt LR (2010) Obstructive sleep apnea syndrome in the Sao Paulo epidemiologic sleep study. Sleep Med 11(5): 441-446.

2. Heinzer R, Vat S, Marques Vidal P, Marti Soler H, Andries D, et al. (2015) Prevalence of sleep-disordered breathing in the general population: 


\section{Current Research in Diabetes \& Obesity Journal}

the HypnoLaus study. Lancet Respir Med 3(4): 310-318.

3. Nock NL, Li L, Larkin EK, Patel SR, Redline S (2009) Empirical evidence for "syndrome Z": a hierarchical 5-factor model of the metabolic syndrome incorporating sleep disturbance measures. Sleep 32(5): 615-622.

4. Xu S, Wan Y, Xu M, Ming J, Xing Y, et al. (2015) The association between obstructive sleep apnea and metabolic syndrome: a systematic review and meta-analysis. BMC Pulm Med 15: 105.

5. Carneiro G, Flório RT, Zanella MT, Pradella Hallinan M, Ribeiro Filho FF, et al. (2012) Is mandatory screening for obstructive sleep apnea with polysomnography in all severely obese patients indicated? Sleep Breath 16(1): 163-168.

6. Pujante P, Abreu C, Moreno J, Barrero EA, Azcarate P, et al. (2013) Obstructive sleep apnea severity is associated with left ventricular mass independent of other cardiovascular risk factors in morbid obesity. J Clin Sleep Med 9(11): 1165-1171

7. Dumitrache Rujinski S, Dinu I, Călcăianu G, Erhan I, Cocieru A, et al. (2014) Metabolic profile in obese patients with obstructive sleep apnea. A comparison between patients with insulin resistance and with insulin sensitivity. Pneumologia 63(2):100-102, 104-106.

8. Lisi E, Faini A, Bilo G, Lonati LM, Revera M, et al. (2015) Diastolic dysfunction in controlled hypertensive patients with mild-moderate obstructive sleep apnea. Int J Cardiol 187: 686-692.

9. Cao Z, Zhang P, He Z, Yang J, Liang C, et al. (2016) Obstructive sleep apnea combined dyslipidemia render additive effect on increasing atherosclerotic cardiovascular diseases prevalence. Lipids Health Dis 15: 98.

10. Lurie A (2011) Cardiovascular disorders associated with obstructive sleep apnea. Adv Cardiol 46:197-266.

11. Drager LF, Togeiro SM, Polotsky VY, Lorenzi Filho G (2013) Obstructive sleep apnea: a cardiometabolic risk in obesity and the metabolic syndrome. J Am Coll Cardiol 62(7): 569-576.

12. Schlatzer C, Schwarz EI, Sievi NA, Clarenbach CF, Gaisl T, et al. (2016) Intrathoracic pressure swings induced by simulated obstructive sleep apnoea promotearrhythmias in paroxysmal atrial fibrillation. Europace 18(1): 64-70.

13. Dempsey JA, Veasey SC, Morgan BJ, O’Donnell CP (2010) Pathophysiology of sleep apnea. Physiol Rev 90(1): 47-112.

14. Bublitz MH, Monteiro JF, Caraganis A, Martin S, Parker J, et al. (2017) Obstructive sleep apnea in gestational diabetes: a pilot study of the role of the hypothalamic-pituitary-adrenal axis. J Clin Sleep Med

15. Carneiro G, Ribeiro Filho FF, Togeiro SM, Tufik S, Zanella MT (2007) Interactions between obstructive sleep apnea syndrome and insulin resistance. Arq Bras Endocrinol Metabol 51(7).

16. Vgontzas AN (2008) Does obesity play a major role in the pathogenesis of sleep apnoea and its associated manifestations via inflammation, visceral adiposity, and insulin resistance? Arch Physiol Biochem 114(4): 211-223.

17. Kim NH, Cho NH, Yun CH, Lee SK, Yoon DW, et al. (2013) Association of obstructive sleep apnea and glucose metabolism in subjects with or without obesity. Diabetes Care 36(12): 3909-3915

18. de Lima FF, Mazzotti DR, Tufik S, Bittencourt L (2016) The role inflammatory response genes in obstructive sleep apnea syndrome: a review. Sleep Breath 20(1): 331-338.

19. Wang X, Yu Q Yue H, Zhang J, Zeng S, et al. (2016) Circulating endocannabinoids and insulin resistance in patients with obstructive sleep apnea. Biomed Res Int 2016: 9782031.

20. Punjabi NM, Sorkin JD, Katzel LI, Goldberg AP, Schwartz AR, et al. (2002) Sleep-disordered breathing and insulin resistance in middleaged and overweight men. Am J Respir Crit Care Med 165(5): 677-682.

21. Punjabi NM, Shahar E, Redline S, Gottlieb DJ, Givelber R, et al. (2004) Sleep heart health study investigators. Sleep disordered breathing, glucose intolerance, and insulin resistance: the sleep heart health Study. Am J Epidemiol 160(6): 521-530.

22. Kritikou I, Basta M, Vgontzas AN, Pejovic S, Liao D, et al. (2014) Sleep apnoea, sleepiness, inflammation and insulin resistance in middleaged males and females. Eur Respir J 43(1): 145-155.

23. Drager LF, Li J, Shin MK, Reinke C, Aggarwal NR, et al. (2012) Intermittent hypoxia inhibits clearance of triglyceride-rich lipoproteins and inactivates adipose lipoprotein lipase in a mouse model of sleep apnoea. Eur Heart J 33(6): 783-790.

24. Liu A, Lamendola C, Ariel D, Abbasi F, Kim SH, et al. (2015) Usefulness of fetuin-A to predict risk for cardiovascular disease among patients with obstructive sleep apnea. Am J Cardiol 116(2): 219-224.

25. Zhou M, Zhu L, Cui X, Feng L, Zhao X, et al. (2016) The triglyceride to high-density lipoprotein cholesterol (TG/HDL-C) ratio as a predictor of insulin resistance but not of $\beta$ cell function in a Chinese population with different glucose tolerance status. Lipids Health Dis 15: 104.

26. Vekic J, Joppa P, Habalova V, Tisko R, Zeljkovic A, et al. (2016) Relationship between the apolipoprotein E genotype and LDL particle size in patients with obstructive sleep apnea. Angiology 67(10): 937 944.

27. Pellegrino R, Mazzotti DR, Guindalini C, Santos Silva R, Bittencourt LR et al. (2011) Apolipoprotein E polymorphisms and sleep quality in obstructive sleep apnea syndrome. Clin Chim Acta 412(23-24): 22232227.

28. Varvarigou V, Dahabreh IJ, Malhotra A, Kales SN (2011) A review of genetic association studies of obstructive sleep apnea: field synopsis and meta-analysis. Sleep 34(11): 1461-1468.

29. Adedayo AM, Olafiranye O, Smith D, Hill A, Zizi F, et al. (2014) Obstructive sleep apnea and dyslipidemia: evidence and underlying mechanism. Sleep Breath 18(1): 13-18. 
This work is licensed under Creative Commons Attribution 4.0 Licens

DOI: 10.19080/CRDOJ.2018.05.555660
Your next submission with Juniper Publishers will reach you the below assets

- Quality Editorial service

- Swift Peer Review

- Reprints availability

- E-prints Service

- Manuscript Podcast for convenient understanding

- Global attainment for your research

- Manuscript accessibility in different formats ( Pdf, E-pub, Full Text, Audio)

- Unceasing customer service

Track the below URL for one-step submission https://juniperpublishers.com/online-submission.php 